Letter to the Editor

\title{
Comment on "Woody Tissue Respiration in Stems of Red Pine (Pinus densiflora) Trees"
}

\author{
Jaeil Yoo and Joon Kim* \\ Global Environment Laboratory, Department of Atmospheric Sciences, Yonsei University, \\ 134 Shinchon, Seodaemun, Seoul, 120-749, Korea \\ (Received 4 February 2008, Accepted 10 March 2008)
}

\author{
편집장 통신 \\ “소나무(Pinus densiflora) 줄기의 목부조직호흡” 논문에 대한 의견 \\ 유재일 · 김 준* \\ 연세대학교 대기과학과, 지구환경연구소 \\ (2008년 2월 4일 접수; 2008년 3월 10일 수락)
}

\begin{abstract}
Typically, soil respiration accounts for most of the ecosystem respiration. According to recent studies on ecosystem respiration, stem respiration could be even larger than leaf respiration, which is generally known to be the second largest component (e.g., Bolstad et al., 2004; McGuire and Teskey, 2004; Guan et al., 2006; Tang et al., 2008). For example, in terms of cumulative annual soil respiration, Tang et al. (2008) reported that the stem respiration (per unit ground area in $\mathrm{m}^{2}$ ) in the old-growth hardwood-dominated and hemlock-dominated stands in northern Michigan, USA accounted for 13 and $22 \%$ of the total ecosystem respiration, respectively. Despite its relative importance, few studies have dealt with stem respiration. Therefore, the recent contribution of Kim et al. (2007a) is opportune and important. The authors measured stem respiration (per unit surface area of the enclosed stem in $\mathrm{m}^{2}$ ) of red pine (Pinus densiflora) using an open flow system, which ranged from 0.25 to $0.55 \mu \mathrm{mol} \mathrm{m}{ }^{-2} \mathrm{~s}^{-1}$ in the winter and from 1.25 to $1.63 \mu \mathrm{mol} \mathrm{m}{ }^{-2} \mathrm{~s}^{-1}$ in the summer. Although the authors have used the term, "total respiration" in a vague manner, they concluded that the woody tissue respiration in the stems of red pines during the summer amounted for $\sim 50 \%$ of the total respiration rates. We agree with the authors that stem respiration could be an important
\end{abstract}

Corresponding Author: Joon Kim (joon-kim@yonsei.ac.kr) component of the carbon cycle in a red pine forest ecosystem, but we disagree on the authors' method of calculating the stem respiration rate, and their analysis and interpretation of the results.

\section{REPRESENTATIVENESS OF THE SAMPLED DATA}

The authors have used only three and a half consecutive days of measurements in the summer and 18 days in the winter to represent the seasonal stem respiration, which is hardly justified particularly for the summer season. Such a limited dataset was further analyzed to quantify the temperature response function such as the $Q_{10}$ factor for each season. A year-long dataset seems to be available for the same site according to Kim et al. (2007b) which may provide data with a wide range of temperature and from different growth stages. Then, the similar analyses based on the whole year's measurements would better demonstrate the authors' conclusion.

\section{EVALUATION OF $Q_{10}$ BY REGRESSION ANALYSIS}

We note that there is a sizable offset between the two 


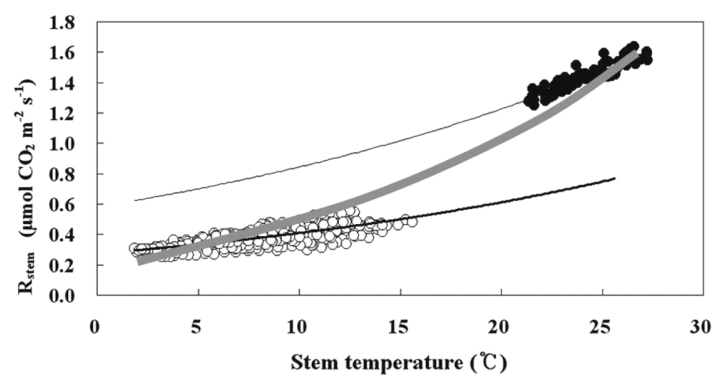

Fig. 1. Comparison of the relationships between hourly mean stem temperature and woody tissue respiration rate in summer $(\bigcirc)$ and winter $(\bigcirc)$. Adapted from Fig. 3, Kim et al. (2007a).

temperature response curves of the summer $(\mathbf{O})$ and winter $(\bigcirc)$ stem respirations (Fig. 1). Based on the assumptions that stem respiration consists of maintenance and growth components, and that the stem respiration in the winter is used only for maintenance, the authors calculated the growth respiration from the difference between the stem respiration in the summer and the winter. However, such an extrapolation is not acceptable because the two datasets do not overlap. In fact, the regression lines in Fig. 1 should be applied only to the range of temperatures encountered during the period of field measurement. Furthermore, such a large and consistent offset between summer and winter seasons has not been reported in other studies (e.g., Bolstad et al., 2004), and a smooth transition (without an offset) of stem respiration should be expected from low temperatures (winter) to high temperatures (summer) (Naishen Liang, personal communication). Again, we suggest the authors to draw one regression line (shown as the shaded line in Fig. 1) using both summer and winter data together to evaluate the $Q_{10}$ factor. If at all possible, an analysis based on a whole year-long dataset including spring and fall season measurements would be more convincing.

\section{MASS BALANCE APPROACH}

The authors' estimates of stem respiration by measuring only $\mathrm{CO}_{2}$ efflux to the atmosphere are based on the assumptions that (1) all $\mathrm{CO}_{2}$ efflux detected by the measurement system is originated from stem tissues and (2) there is no escape of $\mathrm{CO}_{2}$ except to the atmosphere. These assumptions should be clearly mentioned by the authors prior to any further analysis and discus-

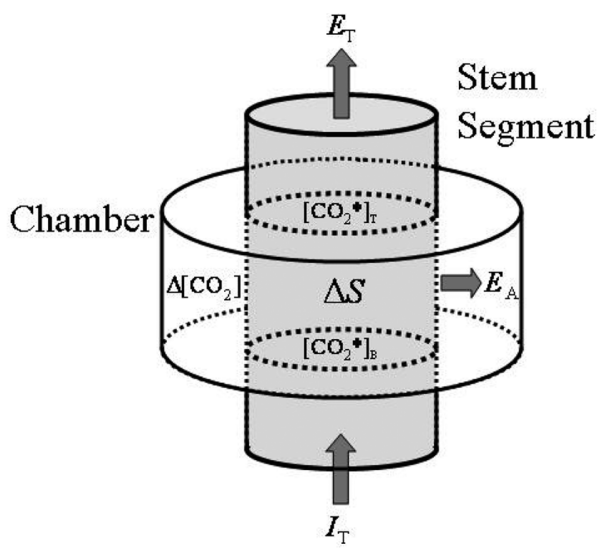

Fig. 2. Conceptual schematic of $\mathrm{CO}_{2}$ flux within and from a stem segment enclosed with a chamber system. $E_{A}$ is efflux to atmosphere; $I_{T}$ and $E_{T}$ are dissolved $\mathrm{CO}_{2}$ entering and leaving the segment in flowing sap; $\Delta S$ is change in internal $\mathrm{CO}_{2}$ concentration in sap flow over time; $\Delta\left[\mathrm{CO}_{2}\right]$ is the difference between concentrations of $\mathrm{CO}_{2}$ of air flowing into and out of the chamber; $\left[\mathrm{CO}_{2}^{*}\right]_{T}$ and $\left[\mathrm{CO}_{2}^{*}\right]_{B}$ are top and bottom concentrations of $\mathrm{CO}_{2}$ in the stem segment, respectively.

sion. According to McGuire and Teskey (2004), dissolved $\mathrm{CO}_{2}$ can be transported into and out of the stem through the xylem. They suggested a mass balance approach that accounts for $\mathrm{CO}_{2}$ efflux from the stem to the atmosphere, transport efflux and influx of $\mathrm{CO}_{2}$ through xylem and storage flux as (McGuire and Teskey, 2004):

$$
R_{S}=E_{A}+\left(E_{T}-I_{T}\right)+\Delta S
$$

where $R_{\mathrm{s}}$ is respiration rate of a segment of stem ( $\mu \mathrm{mol}$ $\mathrm{CO}_{2} \mathrm{~m}^{-3}$ sapwood s${ }^{-1}$ ); $E_{\mathrm{A}}$ is efflux to atmosphere (i.e., $\mathrm{CO}_{2}$ leaving the segment by diffusion through bark); transport influx $\left(E_{\mathrm{T}}\right)$ and transport efflux $\left(I_{\mathrm{T}}\right)$ are dissolved $\mathrm{CO}_{2}$ entering and leaving the segment in flowing sap; and storage flux $(\Delta S)$ is the increase or decrease in mean $\mathrm{CO}_{2}$ concentration in sap flow over time. Below, for completeness, we provided a conceptual schematic of $\mathrm{CO}_{2}$ flux from and within a stem segment of a tree (Fig. 2) and defined all three terms on the right hand side of Eq. (1). Following McGuire and Teskey (2004),

$$
E_{A}=\left(f_{A} / v\right) \Delta\left[\mathrm{CO}_{2}\right]
$$

where $E_{\mathrm{A}}$ is in units of $\mu \mathrm{mol} \mathrm{CO}_{2} \mathrm{~m}^{-3}$ sapwood s $\mathrm{s}^{-1} ; f_{A}$ is rate of the air flow through a chamber surrounding the stem segment $\left(\mathrm{mol} \mathrm{s}^{-1}\right) ; v$ is the sapwood volume of the 
stem segment $\left(\mathrm{m}^{3}\right)$; and $\Delta\left[\mathrm{CO}_{2}\right]$ is the difference between concentrations of $\mathrm{CO}_{2}$ of air flowing into and out of the chamber $\left(\mu \mathrm{mol} \mathrm{mol}{ }^{-1}\right)$.

$$
E_{T}-I_{T}=\left(f_{S} / v\right)\left(\left[\mathrm{CO}_{2}^{*}\right]_{T}-\left[\mathrm{CO}_{2}^{*}\right]_{B}\right)
$$

where $f_{S}$ is the rate of sap flow through the segment (1 $\left.\mathrm{s}^{-1}\right) ;\left[\mathrm{CO}_{2}^{*}\right]$ is $\left[\mathrm{CO}_{2}\right]$ in xylem sap, which is measured at the top and bottom of the chamber $\left(\mu \mathrm{mol} \mathrm{CO}_{2} \mathrm{I}^{-1}\right)$; and thus $E_{\mathrm{T}}$ and $I_{\mathrm{T}}$ are also in units of $\mu \mathrm{mol} \mathrm{CO}_{2} \mathrm{~m}^{-3}$ sapwood $\mathrm{s}^{-1}$. Finally,

$$
\Delta S=\left(\left[\overline{\mathrm{CO}_{2}^{*}}\right]_{T_{2}}-\left[\overline{\mathrm{CO}_{2}^{*}}\right]_{T_{1}}\right) L /\left(T_{2}-T_{1}\right)
$$

where $\left[\overline{\mathrm{CO}_{2}^{*}}\right] T_{1}$ and $\left[\overline{\mathrm{CO}_{2}^{*}}\right] T_{2}$ are means of top and bottom $\left[\mathrm{CO}_{2}^{*}\right]$ in the stem segment at time $T_{1}$ and $T_{2}$ in seconds, respectively, and $\Delta S$ is in units of $\mu \mathrm{mol} \mathrm{CO}_{2}$ $\mathrm{m}^{-3}$ sapwood $\mathrm{s}^{-1}$.

The authors considered only the first term, $E_{\mathrm{A}}$, on the right hand side of Eq. (1). However, McGuire and Teskey (2004) argue that measurements of $\mathrm{CO}_{2}$ efflux alone do not account for all the $\mathrm{CO}_{2}$ produced by stem respiration. They showed that the contribution of other terms (i.e., $\left(E_{T}-I_{T}\right)$ and $\Delta S$ ) can be much greater than that of $E_{\mathrm{A}}$. Furthermore, their relative contribution demonstrates not only diurnal variation but also possibly seasonal variation (because bark permeability may change seasonally with environmental conditions and with tree size and height). Significant differences in relative contributions of individual components in Eq. (1) between daytime and nighttime may cause an artifact in fitting a regression curve for a $Q_{10}$ estimation particularly when daytime and nighttime data are combined and used for analysis.

\section{CONVERSION OF UNITS BETWEEN AREA AND VOLUME BASIS}

As clearly indicated in Eqs. (1)-(4), it should be also noted that the authors estimated $E_{\mathrm{A}}$ per unit stem surface area and not per sapwood volume basis. This leads to our final comment on the computation of stem respiration by Kim et al. (2007a). In recent studies on ecosystem respiration, measured stem respiration rates per unit stem surface area are converted to rates per unit sapwood volume based on tree diameter at breast height (DBH) and sapwood depth. And then, the converted stem respiration rates per unit sapwood volume is converted to rates per unit ground area by multiplying unit sapwood volume per unit ground area (e.g., Bolstad et al., 2004; Tang et al., 2008). Such conversion of the rates to per unit ground area would be particularly useful when the components of the carbon budget of the whole forest ecosystem are considered on a longer term basis.

\section{ACKNOWLEDGEMENTS}

The authors were supported by grants from "CarboEastAsia" A3 Foresight Program of the Korea Science and Engineering Foundation; the Sustainable Water Resources Research Center for 21st Century Frontier Research Program (code: 1-8-3); and the BK21 Program of the Ministry of Education and Human Resources Management of Korea. We are grateful to Dr. Hyojung Kwon for her comments on an early draft of this letter.

\section{REFERENCES}

Bolstad, P. V., K. J. Davis, J. Martin, B. D. Cook, and W. Wang, 2004: Component and whole-system respiration fluxes in northern deciduous forests. Tree Physiology 24(5), 493-504.

Guan, D., J. Wu, X. Zhao, S. Han, G. Yu, X. Sun, and C. Jin, 2006: $\mathrm{CO}_{2}$ fluxes over an old, temperate mixed forest in northeastern China. Agricultural and Forest Meteorology 137(3-4), 138-149.

Kim, M. H., K. Nakane, Y. E. Na, and J. T. Lee, 2007a: Woody tissue respiration in stems of red pine. Korean Journal of Agricultural and Forest Meteorology 9(3), 203-208.

Kim, M. H., K. Nakane, J. T. Lee, H. S. Bang, and Y. E. Na, 2007b: Stem and branch maintenance respiration of Japanese red pine stand. Forest Ecology and Management 243, 283-290.

McGuire, M. A., and R. O. Teskey, 2004: Estimating stem respiration in trees by a mass balance approach that accounts for internal and external fluxes of $\mathrm{CO}_{2}$. Tree Physiology 24(5), 571-578.

Tang, J., P. V. Bolstad, A. R. Desai, J. G. Martin, B. D. Cook, K. J. Davis, and E. V. Carey, 2008: Ecosystem respiration and its components in an old-growth forest in the Great Lakes region of the United States. Agricultural and Forest Meteorology 148(2), 171-185. 